\title{
Recent Trends in California Hispanic Fertility Rates- a Comparative Analysis
}

\author{
Clark A. Davis and J. Joshua Brown \\ California State University, Chico
}

\begin{abstract}
Resumen
In this article we did a comparative analysis of recent trends and differentials in Hispanic fertility rates in the State of California. Hispanics, largely composed of individuals of Mexican origins, were the largest racial/ethnic minority population in the State of California from 1999 to 2001, composing roughly 30 percent of the population, contributed approximately 50 percent of the births during this period. Hispanics, compared to other racial/ethnic groups, have high teenage fertility rates, which persist throughout the reproductive years. Hispanic total fertility rates were well above replacement level fertility and higher than those of other racial/ethnic populations. Two prime policy issues related to human reproduction emerged from an analysis of the data-education and medical care. Although teenage fertility rates declined for all racial/ethnic groups during this period, they still remain high, especially for Hispanics and also for Blacks and American Indians, highlighting the need for education on human reproduction for teenagers. With high teenage fertility rates and a diverse racial/ethnic population, the need for more pervasive prenatal care, especially in the first trimester, also emerged as a significant policy issue.

(c) 2003 Californian Journal of Health Promotion. All rights reserved.

En este artículo hicimos un análisis comparativo de tendencias recientes y diferenciales en las tasas de fertilidad de hispanos en el estado de California. Hispanos, los cuales están compuestos mayormente por individuos de origen Mexicano, fueron el grupo étnico/racial mas grande de la población minoritaria en el estado de California desde el 1999 a el 2001, de manera que componen más o menos 30 porciento de la población y contribuyen a aproximadamente 50 porciento de los nacimientos en este periodo. Hispanos, comparados con otros grupos étnicos/raciales, tienen altas tasas de fertilidad adolescente, las cuales persisten a través de sus años reproductivos. Las tasas totales de fertilidad para Hispanos estuvieron bastante sobre el nivel de reemplazo de fertilidad y más altas que aquellas de otras poblaciones étnicas/raciales. Dos asuntos de política relacionados a la reproducción humana salieron del análisis de la data- educación y cuidado médico. Aunque las tasas de fertilidad para adolescentes disminuyó para todos los grupos étnicos/raciales en este periodo, todavía permanecen muy altas, especialmente para los hispanos pero también para afro-americanos e Indios Americanos, señalando la necesidad de educar a nuestros adolescentes acerca de la reproducción humana. Con las altas tasas de fertilidad de adolescentes y una población étnica/racial tan diversa, existe la necesidad para cuidados prenatales más permeables, especialmente en el primer trimestre de embarazo, lo cual también surgió ser un tema de política muy significante.
\end{abstract}

Keywords: California, Hispanic, fertility, minorities

\section{Introduction}

California, because of its unique position among the states in the United States-being the largest state in the Union (U. S. Census, 2000b), the fifth largest economy in the world (State of California, 2000), possessing a large Hispanic 
Historically, migration has played a significant role in the growth of California's population. However, natural increase, the excess of births over deaths, has accounted for more than 80 percent of the growth during the decade of the 1990s (Johnson, Hill \& Heim, 2001). Of the three components of what demographers refer to as population process (fertility, mortality and migration), fertility, actual human reproduction, has the greatest impact on age and sex, often referred to as population structure, the aging of the population and population composition. Thus, trends and differences in racial/ethnic fertility rates over time can alter the nature and composition of a population (Weeks, 2002).

According to the United States Census Bureau, there were 10,966,556 Hispanics in the State of California in 2000. Of these, the overwhelming majority, 8,455,926 or 77.1 percent, were of Mexican origin, 1.3 percent were Puerto Rican, 0.7 percent Cuban and 21.0 percent Other Hispanic or Latino (U. S. Census, 2000a). Thus, Hispanics of Mexican ancestry are the largest Hispanic population of California and historically have had high fertility rates.

Although Hispanics of Mexican origin are the largest Hispanic population in California and have historically had high fertility rates, it must be kept in mind that fertility is a complex behavior which is influenced by a host of variables. When we speak of Hispanic fertility rates of those of Mexican origin, we are speaking of a diverse group of people with differences between and among those of this ancestry. For example, there are differential fertility rates between those of Mexican origin who were foreign born, those born in the United States and between those who are first, second and third generation immigrants (Hill \& Johnson, 2002). Fertility is, indeed, a complex behavior.

The purpose of this study is to analyze recent aggregate trends and differentials in Hispanic fertility rates relative to other racial/ethnic populations in the State of California from 1999 to 2001.

\section{Methods of the Study}

Data for this study were obtained from the State of California, California Department of Health Services Vital Statistics Query System, Center for Health Statistics website. Ethnicity was determined and tabulated using the "first listed" race only given by the respondents. Whites, Blacks, American Indians and Asian/Pacific Islanders exclude those of Hispanic ethnicity. Hispanic ethnicity, however, includes any race category. Asian/Pacific Islanders includes all Asians, Indians (East), Filipinos, Hawaiians, Guamanians and Samoans. Other non-Asians, not stated and unknown are included in the White race category. Birth records for the Query System were obtained from the State of California Department of Health Services with population data by age, sex and race/ethnicity secured from the State of California, Department of Finance (State of California, 2002).

For purposes of this analysis, births from the Query System for females aged 15-17 and 18-19 were combined into a 15-19 age category. The number of births to teenagers under age 15 was added to the 15-19 age category. Similarly, births to women over age 44 were added to those aged 40-44, which slightly increased the agespecific fertility rates in the $15-19$ and $40-44$ age categories.

The measures of fertility utilized in this study were age-specific fertility rates and the total fertility rate. Age-specific fertility rates, the best overall measure of fertility, are calculated by dividing the number of births for women aged $\mathrm{x}$ to $x+5$ (women are generally grouped into fiveyear age intervals) by the midyear population of women aged $\mathrm{x}$ to $\mathrm{x}+5$, multiplied by a constant of 1,000. The formula for age-specific fertility rates is:

$$
\text { ASFR }=\frac{\text { Number of live births to women aged } \times \text { to } \times+5}{\text { Midyear population of women aged } \times \text { to } \times+5} \times 1,000
$$


From the data provided by the Query System, total fertility rates, the best cross-sectional measure of fertility, were calculated by summing the age-specific fertility rates for each five-year interval ( $x$ to $x+5)$, multiplying the result by 5 (the length of the class interval) and dividing the result by 1,000 , which expresses the total fertility rates in terms of rates per woman. In other words, the total fertility rate is a synthetic measure of fertility. It represents the average number of children a hypothetical woman or cohort of women would bear if they passed through their reproductive years, 15-44, with no mortality and exposed to the same age-specific fertility rates as the women during the year for which the age-specific fertility rates were calculated. The formula for the total fertility rate is:

$$
\mathrm{TFR}=\frac{(\text { Sum ASF }) 5}{1,000}
$$

\section{Analysis of the Data}

Number of Births

It is important to view demographic data at the macro or absolute level, which can sometimes be masked when one limits the examination to rates per 1,000 live births, to get an overall perspective of demographic events before analyzing specifics. Table 1 provides us with such an opportunity. There were 1,576,729 live births in the State of California from 1999 to 2001 of which 768,207, or 48.7 percent, were Hispanic-increasing from 48.1 percent in 1999 to 49.5 percent in 2001. During the same period, Hispanics accounted for approximately 31 percent of the state's population. The Whites/ Others/ Unknown category was almost a mirror image of Hispanics, accounting for approximately 50 percent of the population and 33 percent of the live births. Asian/Pacific Islanders and Blacks had live births in proportion to their composition in the population, fluctuating slightly in the 11 and 6 percent ranges respectively. Thus, Hispanics were contributing live births disproportionately to their composition in the state's population from 1999 to 2001.

Table 1

Number of Live Births, Percentage of Live Births and Percent of the Population for Hispanics and Other Racial/Ethnic Groups in the State of California, 1999-2001

\begin{tabular}{|l|r|r|r|}
\hline \multicolumn{1}{|c|}{$\begin{array}{c}\text { Year } \\
\text { Race/Ethnicity }\end{array}$} & $\begin{array}{c}\text { Number } \\
\text { of Live } \\
\text { Births }\end{array}$ & $\begin{array}{c}\text { Percent } \\
\text { of Live } \\
\text { Births }\end{array}$ & $\begin{array}{r}\text { Percent of } \\
\text { Population }\end{array}$ \\
\hline $\mathbf{1 9 9 9}$ & & & \\
\hline Hispanics & 249,253 & 48.1 & 30.4 \\
\hline Asian/Pacific Islanders & 57,046 & 11.0 & 11.3 \\
\hline Blacks & 34,136 & 6.6 & 6.8 \\
\hline Whites/Others/Unknown & 175,137 & 33.8 & 50.9 \\
\hline American Indians & 2,501 & 0.5 & 0.6 \\
\hline Totals & 518,073 & 100.0 & 100.0 \\
\hline & & & \\
\hline $\mathbf{2 0 0 0}$ & & & \\
\hline Hispanics & 257,958 & 48.6 & 30.8 \\
\hline Asian/Pacific Islanders & 62,845 & 11.8 & 11.5 \\
\hline Blacks & 33,752 & 6.4 & 6.7 \\
\hline Whites/Others/Unknown & 174,490 & 32.8 & 50.3 \\
\hline
\end{tabular}




\begin{tabular}{|l|r|r|r|}
\hline $\begin{array}{c}\text { Year } \\
\text { Race/Ethnicity }\end{array}$ & $\begin{array}{c}\text { Number } \\
\text { of Live } \\
\text { Births }\end{array}$ & $\begin{array}{c}\text { Percent } \\
\text { of Live } \\
\text { Births }\end{array}$ & $\begin{array}{r}\text { Percent of } \\
\text { Population }\end{array}$ \\
\hline American Indians & 2,240 & 0.4 & 0.6 \\
\hline Totals & 531,285 & 100.0 & 99.9 \\
\hline $\mathbf{2 0 0 1}$ & & & \\
\hline Hispanics & & & \\
\hline Asian/Pacific Islanders & 260,996 & 49.5 & 31.3 \\
\hline Blacks & 61,426 & 11.6 & 11.8 \\
\hline Whites/Others/Unknown & 32,469 & 6.2 & 6.7 \\
\hline American Indians & 170,251 & 32.3 & 49.7 \\
\hline Totals & 2,229 & 0.4 & 0.6 \\
\hline
\end{tabular}

Source: Department of Health Services: Birth Records. State of California, Department of Finance- years 1999, 2000 and 2001. Population: 1997-2040 Population Projections by Age, Sex, and Race/Ethnic Detail, December 1998.

Ethnicity results and queries are tabulated using the "first listed" race only. White, Black, American Indian and /Pacific Islanders exclude Hispanic ethnicity. Hispanic includes any race category. Asian/Pacific Islanders. includes all Asians, Indian (East), Filipino, Hawaiian, Guamanian, Samoan. Other non-Asian, not stated and unknown are included in White race category. Data retrieved from California Department of Health Services Vital Statistics Query System: http://www.applications.dhs.ca.gov/vsq/default.asp

\section{Age-Specific Fertility Rates}

Age-specific fertility rates, considered by demographers to be the best overall measure of fertility-controlling both for age and sex- clearly demonstrates and pinpoints where differences occurred between Hispanic and other racial/ethnic groups in the State of California from 1999 to 2001 (see Table 2).

Table 2

Age-Specific Fertility Rates for Hispanics and Other Racial/Ethnic Groups in the State of California, 1999-2001

\begin{tabular}{|c|c|c|c|c|c|c|}
\hline \multirow[t]{2}{*}{$\begin{array}{c}\text { Year } \\
\text { Race/Ethnicity }\end{array}$} & \multicolumn{6}{|c|}{$\begin{array}{c}\text { Age-Specific Fertility Rates } \\
\text { (per 1,000 live births) }\end{array}$} \\
\hline & 15-19 & $20-24$ & $25-29$ & $30-34$ & $35-39$ & $40-44$ \\
\hline \multicolumn{7}{|l|}{1999} \\
\hline Hispanic & 94.6 & 200.7 & 177.9 & 111.8 & 52.6 & 13.9 \\
\hline Asian/Pacific Islanders & 19.4 & 55.8 & 112.4 & 119.8 & 59.3 & 13.6 \\
\hline Blacks & 64.3 & 123.0 & 99.0 & 70.1 & 34.3 & 8.1 \\
\hline Whites/Others/Unknown & 23.1 & 67.0 & 87.8 & 83.2 & 41.3 & 9.7 \\
\hline American Indians & 63.7 & 113.0 & 82.6 & 52.6 & 22.3 & 5.2 \\
\hline \multicolumn{7}{|l|}{2000} \\
\hline Hispanic & 92.2 & 199.9 & 187.0 & 116.2 & 54.5 & 14.7 \\
\hline Asian/Pacific Islanders & 17.3 & 56.1 & 120.1 & 134.4 & 66.0 & 14.5 \\
\hline Blacks & 61.1 & 120.0 & 101.3 & 71.5 & 35.7 & 8.4 \\
\hline Whites/Others/Unknown & 20.9 & 64.7 & 87.5 & 87.4 & 43.1 & 10.6 \\
\hline
\end{tabular}




\begin{tabular}{|l|r|r|r|r|r|r|}
\hline $\begin{array}{c}\text { Year } \\
\text { Race/Ethnicity }\end{array}$ & \multicolumn{7}{|c|}{$\begin{array}{c}\text { Age-Specific Fertility Rates } \\
\text { (per 1,000 live births) }\end{array}$} \\
\hline & $\mathbf{1 5 - 1 9}$ & \multicolumn{1}{|c|}{$\mathbf{2 0 - 2 4}$} & $\mathbf{2 5 - 2 9}$ & $\mathbf{3 0 - 3 4}$ & \multicolumn{1}{|c|}{$\mathbf{3 5 - 3 9}$} & $\mathbf{4 0 - 4 4}$ \\
\hline American Indians & 49.5 & 98.4 & 76.5 & 50.5 & 22.7 & 5.1 \\
\hline $\mathbf{2 0 0 1}$ & & & & & & \\
\hline Hispanic & & & & & & \\
\hline Asian/Pacific Islanders & 87.6 & 195.6 & 191.2 & 118.0 & 56.7 & 14.5 \\
\hline Blacks & 15.7 & 51.9 & 115.6 & 128.0 & 64.2 & 14.4 \\
\hline Whites/Others/Unknown & 54.7 & 113.1 & 99.3 & 71.7 & 36.5 & 8.9 \\
\hline American Indians & 18.9 & 61.8 & 85.5 & 88.7 & 44.0 & 10.7 \\
\hline & 44.8 & 95.1 & 77.3 & 53.9 & 22.9 & 6.2 \\
\hline
\end{tabular}

Source: Department of Health Services: Birth Records. State of California, Department of Finance- years 1999, 2000 and 2001. Population: 1997-2040 Population Projections by Age, Sex, and Race/Ethnic Detail, December 1998.

Ethnicity results and queries are tabulated using the "first listed" race only. White, Black, American Indian and Asian/Pacific Islanders exclude Hispanic ethnicity. Hispanic includes any race category. Asian/Pacific Islanders includes all Asians, Indian (East), Filipino, Hawaiian, Guamanian, Samoan. Other non-Asian, not stated and unknown are included in White race category. Data retrieved from California Department of Health Services Vital Statistics Query System: http://www.applications.dhs.ca.gov/vsq/default.asp

It is clear from the data in Table 2 that the Hispanic population in the State of California from 1999 to 2001 was experiencing higher agespecific fertility rates than other racial/ethnic groups with few exceptions. Hispanic women had higher age-specific fertility rates at younger ages (15-19), through the prime reproductive years (20-24 and 25-29) and continued to have high fertility rates in the remainder of their reproductive years (30-34, 35-39 and 40-44).

In 1999, Hispanic women aged 15-19 had an age-specific fertility rate of 94.6 , or 94.6 live births per 1,000 Hispanic women aged 15-19. Differences between other racial/ethnic groups ranged from 30.3 to 75.2 live births per 1,000 women respectively for Black and Asian/Pacific Islanders. In other words, Hispanic females in 1999 had 75.2 more live births per 1,000 women aged 15-19 than did Asian/Pacific Islanders.

The trend in differential fertility rates for the 1519 age category persisted through 2001, although age-specific birth rates for all racial/ethnic groups declined during this threeyear period. In 2001, the age-specific birth rate for Hispanic women was 87.6, or a decline of 7 births per 1,000 from 1999; however, Hispanic females still exceed other racial/ethnic groups by rather large margins-ranging from 32.9 to 71.9 births per 1,000 for Black and Asian/Islanders respectively. It is clear from the data that Hispanic females start reproducing at early ages and at much higher levels than do other females of other racial/ethnic groups.

In the prime reproductive years, 20-24 and 2529, age-specific fertility rates for Hispanic females far exceed those of other racial/ethnic groups. Levels stood at 200.7 and 177.9 in 1999 and 195.6 and 191.2 in 2001. Blacks, who had the next highest age-specific fertility rates for the 20-24 age category, were exceeded by Hispanics by 77.7, 79.9 and 82.5 live births per 1,000 women in 1999, 2000 and 2001 respectively. Similar results were noted in the 25-29 age category where Hispanic age-specific fertility rates exceeded Asian/Pacific Islanders, who had the next highest age-specific fertility rates in this age category, by 65.5, 66.9 and 75.6 and Whites/Others/Unknown by 90.1, 99.5 and 105.7 live births per 1,000 women in 1999, 2000 and 2001 respectively. 
Hispanic fertility rates persist at high levels, when compared to other racial/ethnic groups, in the 30-34 and 35-39 age categories (111.8 and 52.6 respectively in 1999 and 118.0 and 56.7 in 2001), although the Asian/Pacific Islanders agespecific fertility rates were higher than those of Hispanics in these age categories (119.8 and 59.3 respectively in 1999 and 128.0 and 64.2 in 2001). Hispanics have high fertility rates starting at early ages and persist at high levels throughout their reproductive years, while Asian/Pacific Islanders postpone their reproduction until their mid-to-late twenties and throughout their thirties. Figure 1 clearly illustrates the high persistent fertility rates of the Hispanic population in 2001 compared to other racial/ethnic categories.

As seen in Table 2, most of the reproduction is completed prior to the commencement of the fortieth year for all racial/ethnic groups in California with Hispanics and Asian/Pacific Islanders having the highest age-specific fertility rates in the 40-44 age category hovering in the low to mid-teens, while American Indians had the lowest age-specific fertility rates in this age category, ranging from 5.2 in 1999 to 6.2 in 2001.

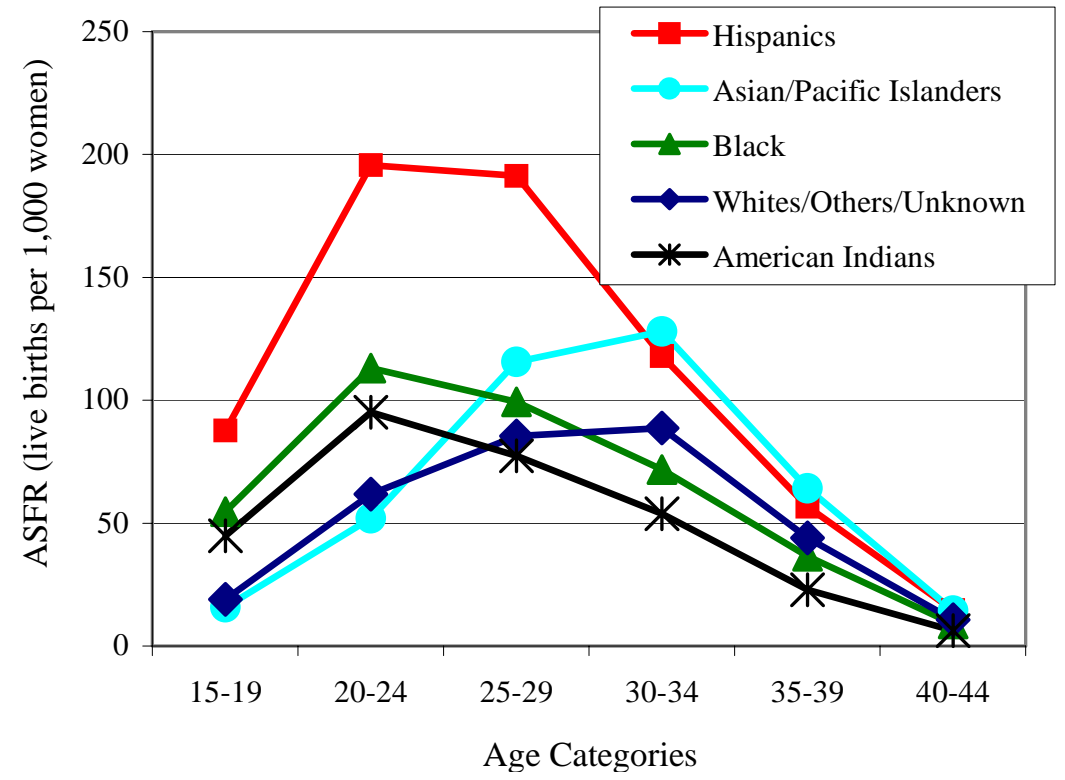

Figure 1

Age-Specific Fertility Rates for Hispanic and Other Racial/Ethnic Groups in the State of California, 2001

Source: Compiled from Department of Health Services: Birth Records. State of California, Department of Financeyears 1999, 2000 and 2001. Population: 1997-2040 Population Projections by Age, Sex, and Race/Ethnic Detail, December 1998.

Ethnicity results and queries are tabulated using the "first listed” race only. White, Black, American Indian and Asian/Pacific Islanders exclude Hispanic ethnicity. Hispanic includes any race category. Asian/Pacific Islanders includes all Asians, Indian (East), Filipino, Hawaiian, Guamanian, Samoan. Other non-Asian, not stated and unknown are included in White race category. Data retrieved from California Department of Health Services Vital Statistics Query System: http://www.applications.dhs.ca.gov/vsq/default.asp 


\section{Total Fertility Rates}

Total fertility rates provide a unique opportunity to analyze reproductive outcomes under the assumption that a specific set of age-specific fertility rates would persist through time. As previously stated, the total fertility rate is a synthetic measure. It represents the average number of children a hypothetical woman or cohort of women would bear if they passed through their reproductive years with no mortality and exposed to the same age-specific fertility rates as the women during the year for which the age-specific fertility rates were calculated. Thus, with the constant in the total fertility rate equal to 1 , it represents a hypothetical average number of children a woman would bear as she passes through the reproductive years of her life.

An analysis of Table 3 clearly illustrates the central role Hispanics are playing in the fertility patterns of the State of California. During the three-year period under analysis, 1999-2001, Hispanics were the only racial/ethnic group in the state that exceeded the average number of children a woman would need to bear to achieve replacement level fertility, which is 2.1. Hispanics exceed the 2.1 figure in all three years with identical total fertility rates of 3.3.

Table 3

Total Fertility Rates for Hispanics and Other Racial/Ethnic Groups in the State of California, 1999-2001

\begin{tabular}{|c|c|}
\hline \multicolumn{1}{c|}{$\begin{array}{c}\text { Year } \\
\text { Race/Ethnicity }\end{array}$} & Total Fertility Rates \\
\hline $\mathbf{1 9 9 9}$ & 3.3 \\
\hline Hispanics & 1.9 \\
\hline Asian/Pacific Islanders & 2.0 \\
\hline Blacks & 1.6 \\
\hline Whites/Others/Unknown & 1.7 \\
\hline American Indians & \\
\hline $\mathbf{2 0 0 0}$ & 3.3 \\
\hline Hispanics & 2.0 \\
\hline Asian/Pacific Islanders & 2.0 \\
\hline Blacks & 1.6 \\
\hline Whites/Others/Unknown & 1.5 \\
\hline American Indians & \\
\hline Hispanics & 3.3 \\
\hline $\mathbf{2 0 0 1}$ & 1.9 \\
\hline Asian/Pacific Islanders & 1.9 \\
\hline Blacks & 1.5 \\
\hline Whites/Others/Unknown & 1.5 \\
\hline American Indians & \\
\hline
\end{tabular}

Source: Department of Health Services: Birth Records. State of California, Department of Finance- years 1999, 2000 and 2001. Population: 1997-2040 Population Projections by Age, Sex, and Race/Ethnic Detail, December 1998.

Ethnicity results and queries are tabulated using the "first listed" race only. White, Black, American Indian and Asian/Pacific Islanders exclude Hispanic ethnicity. Hispanic includes any race category. Asian/Pacific Islanders includes All Asians, Indian (East), Filipino, Hawaiian, Guamanian, Samoan. Other non-Asian, not stated and unknown are included in White race category. Data retrieved from California Department of Health Services Vital Statistics Query System: http://www.applications.dhs.ca.gov/vsq/default.asp 
Blacks and Asian/Pacific Islanders total fertility rates fluctuated between 1.9 and 2.0 between 1999 and 2001, just below replacement fertility level; while the Whites/ Others/ Unknown and American Indians categories fluctuated between 1.5 and 1.7 , substantially below the replacement level. Thus, in 2001 the Hispanic total fertility rate exceeded those of Asian/Pacific Islanders and Blacks by 1.4 children per woman or 73.7 percent; and the White/Others/Unknown and American Indian categories by 1.8 children or 120.0 percent (see Figure 2).
The cumulative effects of high Hispanic agespecific fertility rates throughout the reproductive years resulted in high total fertility rates well above replacement level fertility. Although Asian/Pacific Islanders age-specific rates exceed those of Hispanics in age categories 30-34 and above, their low age-specific fertility rates in the younger age categories resulted in total fertility rates approximately at replacement level-1.9, 2.0 and 1.9 in 1999, 2000 and 2001 respectively.

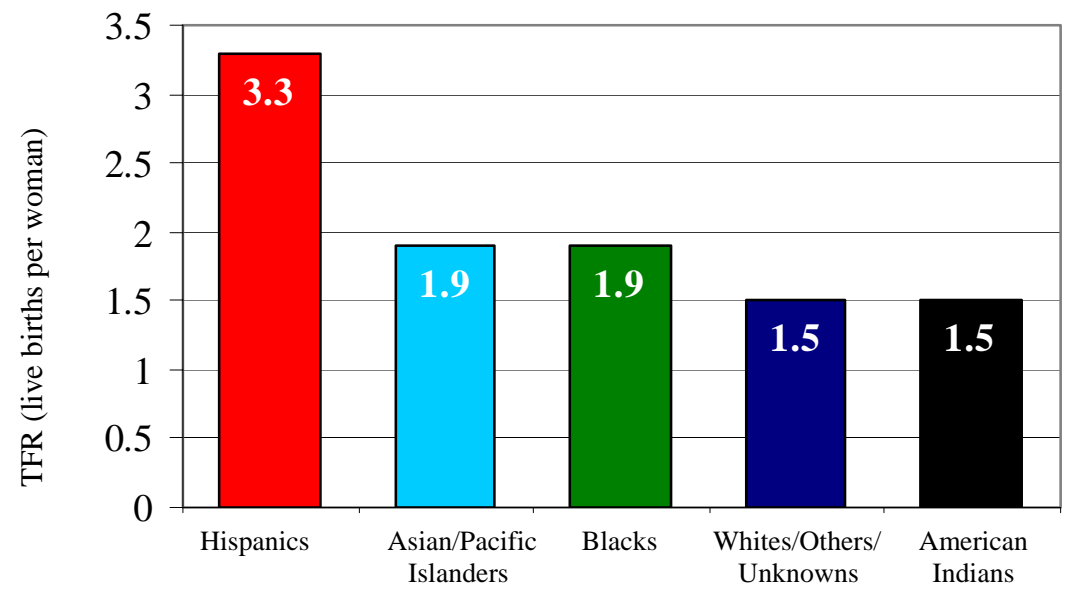

Figure 2

Total Fertility Rates for Hispanics and Other Racial/Ethnic Groups in the State of California, 2001

Source: Compiled from Department of Health Services: Birth Records. State of California, Department of Financeyears 1999, 2000 and 2001. Population: 1997-2040 Population Projections by Age, Sex, and Race/Ethnic Detail, December 1998.

Ethnicity results and queries are tabulated using the "first listed" race only. White, Black, American Indian and Asian/Pacific Islanders exclude Hispanic ethnicity. Hispanic includes any race category. Asian/Pacific Islanders includes all Asians, Indian (East), Filipino, Hawaiian, Guamanian, Samoan. Other non-Asian, not stated and unknown are included in White race category. Data retrieved from California Department of Health Services Vital Statistics Query System: http://www.applications.dhs.ca.gov/vsq/default.asp

\section{Summary}

Clearly, differential racial/ethnic fertility patterns existed in the State of California from 1999 to 2001. Hispanics, the predominant minority group and largely composed of individuals of Mexican descent, had high age- specific fertility rates throughout the reproductive years, especially during the teen years and prime reproductive years from 20 to 29 , resulting in total fertility rates of 3.3 in 1999, 2000 and 2001, which were well beyond the 
replacement level of 2.1, and well beyond those of other racial/ethnic groups.

Explanations for differential racial/ethnic fertility rates have been closely allied with cultural and socioeconomic characteristics. Education has especially played a key role in levels of reproductive performance with fertility being inversely related to educational attainment (Weeks, 2002). Hispanic women in the State of California tend to be less educated than women of other racial/ethnic groups (Johnson, 2001). Furthermore, less educated women have a tendency to marry earlier, also a predictor of high fertility rates. In addition, Hispanic fertility rates in California are influenced by the number of foreign-born females as opposed to nativeborn females. Foreign-born Hispanic females, especially those from Mexican rural areas, have historically had higher fertility rates than nativeborn Hispanics (Hill \& Johnson, 2002). All of these factors combined to create the differential fertility rates that existed between Hispanics and other racial/ethnic groups in California from 1999 to 2001.

\section{Implications}

Two prime public policy issues related to human reproduction emerge from an analysis of the data. They are education and medical care. The need for education about human reproduction is essential for individuals of all ages during the reproductive years and especially important for teenagers. Although teenage birth rates in California declined from 1999 to 2001 and have been declining for a number of years (Johnson,
2003), there were still high age-specific fertility rates in the 15-19 age category, especially for Hispanics but also for Blacks and American Indians. Research data suggest that life chances for children born to teenage mothers are adversely affected when compared to those born to older women (Maynard, 1997). In California, teenage births have increasingly occurred to teenage mothers who have never been married. In 2000, 78 percent of teenage births in California occurred to teenagers who had never been married (Johnson, 2003). Thus there is a glaring need for educational and community programs focused on reproductive issues designed to meet the needs of the diverse racial/ethnic teenage population of California.

The need for medical care during pregnancy is a given; however, there still remains an unfilled need for prenatal care, especially in the first trimester for minority women. For example, in the United States in 2000, approximately 16 percent of Hispanic and Black women did not receive prenatal care during the first trimester of their pregnancies; however, the figure of Hispanic women stood at 27 percent (March of Dimes, 2002). In California from 1998 to 2000, approximately 20 percent of Hispanic and Black women and approximately 27 percent for American Indians or Alaska Natives did not receive medical care in the first trimester of their pregnancies (CDC, 2002). Although trends continue in the direction of improved medical care during the first trimester and throughout the reproductive years, the need for access to medical care during pregnancy still exists.

\section{References}

Centers for Disease Control and Prevention. (2002). Table 7. Early prenatal care according to race and Hispanic origin of mother, geographic division, and state: United States, average annual 1992-94, 1995-97, and 1998-2000. Retrieved March 23, 2003, from http://www.cdc.gov/nchs/data/hus/tables/2002/02hus007.pdf

Hill, L. E., \& Johnson, H. P. (2002). Understanding the future of Californians' fertility: The role of immigrants. Retrieved February 20, 2002, from http://www.ppic.org/content/pubs/R_402LHR.pdf

Johnson, H. P. (2001). The demography of California's immigrants. Retrieved February 20, 2002, from http://www.ppic.org/content/pubs/OP_301HJOP.pdf

Johnson, H. P. (2003). Maternity before maturity: Teen birth rates in California. California Counts, 4(3). Retrieved February 20, 2002, from http://www.ppic.org/content/pubs/CC 203HJCC.pdf 
Johnson, H. P., Hill, L., \& Heim, M. (2001). New trends in newborns: Fertility rates and patterns in California. California Counts, 3(1). Retrieved February 20, 2002, from http://www.ppic.org/content/pubs/CC 801HJCC.pdf

March of Dimes. (2002). Infant health statistics. Retrieved February 26, 2002, http://www.marchofdimes.com/professionals/1525.asp

Maynard, R. A. (Ed.). (1997). Kids having kids: Economic costs and social consequences of teen pregnancy. Washington, DC: Urban Institute Press.

State of California. (2000). California office of trade and investment - Statistics. Retrieved September 22, 2002, from http://www.california.co.za/californiastatistics.htm

State of California. (2002). California department of health services vital statistics query system. Retrieved January 5, 2003, from http://www.applications.dhs.ca.gov/vsq/default.asp

United States Census Bureau. (2000a). Hispanic or Latino origin for the United States, regions, divisions, states, and for Puerto Rico: 2000 (Publication No. PHC-T-10). Retrieved January 5, 2003, from http://landview.census.gov/population/cen2000/phc-t10/tab01-06.pdf

United States Census Bureau. (2000b). Population, housing units, area, and density (geographies ranked by total population): 2000 (Publication No. GCT-PH1-R). Retrieved September 29, 2002, from http://factfinder.census.gov/servlet/GCTTable?ds_name=D\&geo_id=D\&mt_name=DEC_2000_S F1_U_GCTPH1R_US9S\&_lang=en

United States Census Bureau. (2002). California quickfacts from the U.S. Census Bureau. Retrieved September 16, 2002, from http://quickfacts.census.gov/qfd/states/06000.html

Weeks, J. R. (2002). Population: An introduction to concepts and issues (8th ed.). USA: Wadsworth.

Author Information

Clark A. Davis, Ph.D.

Department of Sociology

California State University, Chico

$400 \mathrm{~W}$. First St.

Chico, CA 95929-0002

E-mail: cadavis@csuchico.edu

J. Joshua Brown, M.A. Candidate

Department of Social Science and Special Programs

California State University, Chico

400 W. First St.

Chico, CA 95929-0002

E-mail: jbrown43@mail.csuchico.edu 